Nurmala, T. $\cdot$ A. Yuniarti $\cdot$ W. Firdawati $\cdot$ W.A. Qosim

\title{
Pengaruh pupuk biosilika terhadap pertumbuhan, hasil, dan kekerasan biji tanaman hanjeli (Coix lacryma-jobi L.) varietas batu dan pulut
}

\section{The effect of biosilica fertilizer on growth, yield, and seed hardness of job's tears (Coix lacryma jobi L.) var. stenocarpa and mayuen}

Diterima : 10 Juni 2019/Disetujui : 2 Agustus 2019 / Dipublikasikan : 7 Agustus 2019

CDepartment of Crop Science, Padjadjaran University

\begin{abstract}
The research was conducted to determine the dosage of organic silica that can give the best effect to the growth, yield, and seed hardness of Job's tears. This research was conducted from Desember 2015 to May 2016 at Ciparanje Experiment Station, Jatinangor, West Java in Faculty of Agriculture, Padjadjaran University. The experimental design used Randomized Block Design of twelve treatments and four replication. Treatments consisted of biosilica fertilizer (kg/ha): 0; 150; 300; 450; 600 and 750; that given to two varieties of job's tears: stenocarpa and mayuen. Data were analyzed by Anova ( $\mathrm{F}$ test) at 5\% significance level, then tested by Duncan test at $5 \%$ significance level. The results showed that the biosilica fertilizer influenced panicle number, harvest index; and seed hardness. Dosage of $150 \mathrm{~kg} / \mathrm{ha}$ and 750 $\mathrm{kg} / \mathrm{ha}$ biosilica affected panicle number on Stenocarpa. Dosage of $600 \mathrm{~kg} / \mathrm{ha}$ gave the better harvest index than no silica fertilizer on Mayuen. All of silica dosage gave higher seed hardness than no silica fertilizer on Stenocarpa.
\end{abstract}

Keywords: Job's tears - Growth and yield - Seed hardness

Sari Tujuan dari penelitian adalah untuk mengetahui dosis pupuk silika organik yang tepat yang memberikan pengaruh terbaik terhadap pertumbuhan, hasil, dan kekerasan biji hanjeli (Coix lacryma-jobi L.). Penelitian dilaksanakan di Kebun Percobaan Fakultas Pertanian UNPAD, Ciparanje, Jatinangor, sejak bulan Desember 2015

Dikomunikasikan oleh Agus Wahyudin

Nurmala, T. ${ }^{1} \cdot$ A. Yuniarti ${ }^{1}$. W. Firdawati ${ }^{2}$. W.A. Qosim ${ }^{1}$

1) Staf Pengajar Fakultas Pertanian UNPAD

2) Mahasiswa Pasca Sarjana UNPAD

Korespondensi: tati.nurmala@unpad.ac.id sampai Mei 2016. Rancangan percobaan yang digunakan adalah Rancangan Acak Kelompok (RAK) yang terdiri dari 12 perlakuan dan 4 ulangan. Perlakuan terdiri enam taraf dosis pupuk biosilika (arang kulit biji hanjeli pulut yang mengandung $12 \% \mathrm{SiO}_{2}$ ) masing-masing per ha adalah 0 kg; 150 kg; 300 kg; 450 kg; 600 dan 750 kg pada dua jenis hanjeli batu (var. Stenocarpa) dan pulut (var. Mayuen). Data dianalisis menggunakan Sidik Ragam dengan Uji F pada taraf nyata 5\%, sementara nilai beda dengan Uji Duncan pada taraf nyata 5\%. Hasil penelitian menunjukkan bahwa pupuk biosilika berpengaruh terhadap jumlah malai per rumpun, indeks panen, dan kekerasan biji hanjeli pada kandungan silika tanah tinggi. Dosis $150 \mathrm{~kg} / \mathrm{ha}$ dan $750 \mathrm{~kg} / \mathrm{ha}$ pada hanjeli batu berpengaruh terhadap jumlah malai per rumpun dibandingkan kontrol. Dosis $600 \mathrm{~kg} / \mathrm{ha}$ memberikan IP terbaik dibandingkan kontrol pada hanjeli pulut. Semua dosis silika berpengaruh terhadap kekerasan biji hanjeli batu dibandingkan kontrol.

Kata kunci: Hanjeli • Biosilika • Pertumbuhan dan hasil $\cdot$ Kekerasan biji

\section{Pendahuluan}

Undang-Undang Dasar no 18 pasal 41 mengenai pangan menjelaskan bahwa penganekaragaman pangan merupakan sebuah upaya meningkatkan ketahanan pangan nasional, berbasis potensi sumber daya lokal guna memenuhi pola konsumsi pangan yang beragam, bergizi, seimbang, sehat, dan aman. Rachman dan Ariani (2008) mengungkapkan ada dua tipe penganekaragaman pangan di Indonesia, yaitu 1) penganekaragaman sederhana, yaitu mengan- 
dalkan menu karbohidrat tidak hanya dari satu sumber pangan karbohidrat, misalnya selain nasi juga disubstitusi dengan singkong atau kentang, serta 2) penganekaragaman pangan kompleks adalah pangan yang tidak terbatas pada sumber karbohidrat tapi juga berbasis pada sumber protein, lemak, atau serat. Masyarakat Indonesia dapat mengoptimalkan tanaman serealia maupun umbi-umbian sebagai alternatif pangan non beras.

Hanjeli merupakan salah satu tanaman serealia yang belum banyak dimanfaatkan oleh masyarakat di Indonesia meskipun sudah lama dikenal di masyarakat karena Indonesia adalah bagian dari Indomalaya yang merupakan daerah asal tanaman hanjeli menurut Vavilov. Hanjeli dikenal juga dengan sebutan jali, jelai, japen, adlay (Filipina), Job's tears (Australia), dan mayuen (China), merupakan tanaman yang termasuk family Gramineae, genus Coix.

Budidaya hanjeli belum dilaksanakan secara intensif, karena hanya sebagai tanaman minor dan sporadis, serta dimanfaatkan sebagai tanaman herbal atau suplemen saja. Hanjeli memiliki kandungan komponen gizi utama yaitu karbohidrat. Protein (14\%) dan lemak (4$7,9 \%)$ lebih tinggi dibandingkan biji serealia lainnya. Hanjeli mengandung kalsium yang tinggi $(54 \mathrm{mg} / \mathrm{kg})$ sehingga bisa mengatasi penyakit osteoporosis, juga memiliki nilai indeks glikemik (IG) yang rendah sehingga biji hanjeli atau beras hanjeli dapat dimanfaatkan sebagai pangan fungsional (Nurmala et. al., 2017).

Tanaman hanjeli tumbuh di liar di seluruh Indonesia dengan ekosistem yang beragam, baik di lahan rawa ataupun di lahan kering (Nurmala dan Irwan, 2007). Nurmala et. al. (2017), menyatakan bahwa terdapat faktor pembatas dalam budidaya tanaman hanjeli, yaitu teknologi budidaya yang tepat, teknologi pasca panen, serta informasi pengolahan dan pemasaran. Hal ini menyebabkan petani dengan kelompoknya kurang tertarik dalam mengembangkan komoditas hanjeli.

Teknologi budidaya dengan aplikasi pupuk biosilika atau silika organik, yang berasal dari arang kulit gabah padi, merupakan biosilika yang sangat penting bagi tanaman serealia termasuk hanjeli. Hanjeli dikenal sebagai tanaman akumulator silika yang memiliki peran penting untuk pertumbuhan dan perkembangannya. Silika hanya sebagai unsur tambahan (beneficial element), namun silika memiliki kemampuan untuk mengoptimalkan pertumbuhan dan hasil melalui peningkatan ketahanan terhadap cekaman biotik dan abiotik (Matichencov and Calvet, 2002). Berkurangnya hara silika di dalam tanah disebabkan oleh terangkutnya melalui hasil panen yang terusterusan dengan tanaman yang sama (padi).

Takahashi and Miyake (1977) dalam Djajadi (2013) mengemukakan bahwa tanaman akumulator Si mempunyai kadar Si dalam jaringan daun lebih dari $1 \%$, sedangkan pada tanaman lainnya hanya $0,25 \%$. Pada tanaman tebu yang termasuk family gramineae, $\mathrm{Si}$ disimpan dalam bentuk silica gel $\left(\mathrm{SiO}_{2} \mathrm{nH}_{2} \mathrm{O}\right)$ yang diakumulasi pada jaringan batang dan daun (Meyer and Keeping, 2000). Syafrudin (2011) menjelaskan bahwa pemberian pupuk Si pada jagung dapat memperbesar ukuran tongkol dan meningkatkan hasil. Djajadi (2013) menyatakan pemberian pupuk Si pada tebu 14,2 ton/ha dalam bentuk $\mathrm{CaSiO}_{3}$ per ha meningkatkan hasil tebu 30\%, dari 59,9 - 781 ton/ha. Malivchenkov and Calvert (2002) menyatakan bahwa penambahan pupuk silika dapat meningkatkan kekerasan kulit biji pada tanaman kakao.

Dengan demikian dapat dirumuskan permasalahan penelitian ini adalah bagaimana peranan pupuk silika terhadap peningkatan pertumbuhan dan hasil, serta kekerasan biji hanjeli. Penelitian ini menggunakan hanjeli varietas batu dan varietas pulut.

\section{Bahan dan Metode}

Percobaan ini dilaksanakan di Kebun Percobaan Ciparanje di Jatinangor Fakultas Pertanian UNPAD. Waktu percobaan dimulai dari bulan Februari sampai Juli 2016. Benih yang digunakan dari varietas batu genotip 40 (varietas Stenocarpa) dan jenis pulut genotip 37 (varietas Mayuen) merupakan hasil seleksi Laboratorium Pemuliaan Tanaman dan Produksi Tanaman, Fakultas Pertanian, UNPAD. Pupuk biosilika berasal dari arang sosohan kulit biji hanjeli batu yang mengandung $12 \% \mathrm{SiO}_{2}$, dari Laboratorium Kesuburan Tanah dan Nutrisi Tanaman, Fakultas Pertanian, UNPAD.

Percobaan di lapangan menggunakan Rancangan Acak Kelompok (RAK). Dosis pupuk silika, terdiri dari 6 taraf masing-masing per ha (0 kg; $150 \mathrm{~kg} ; 300 \mathrm{~kg}$; $450 \mathrm{~kg} ; 600 \mathrm{~kg} ; 750 \mathrm{~kg}$ ), 
atau masing-masing per polibag ukuran 50x50 cm yaitu 0g; 4,5 g; 9,0 g; 13,5 g; 18,0 g; 22,5 g. Jumlah perlaluan menjadi 12 kombinasi, diulang empat kali. Kekerasan biji diukur dengan alat Penetrometer. Data hasil penelitian dianalisis sidik ragam dengan uji $\mathrm{F}$ pada taraf nyata $5 \%$, dan uji nilai beda menggunakan Duncan pada taraf nyata $5 \%$.

\section{Hasil dan Pembahasan}

Media tanam tanah yang digunakan dari ordo inceptisol dengan $\mathrm{pH}$ 5,9 dan mengandung kadar silika tanah 22\% (tinggi). Tipe iklim termasuk tipe hujan C3 (Oldeman), cukup untuk pertumbuhan hanjeli. Hasil analisis statistik data variabel, pertumbuhan, hasil, dan kekerasan biji terdapat pada Tabel 1, 2, dan 3.

Hasil penelitian terhadap karakter tinggi tanaman menunjukkan pupuk silika tidak berpengaruh terhadap tinggi tanaman hanjeli dibandingkan tanpa pupuk silika. Tinggi tertinggi $(143,97 \mathrm{~cm})$ pada hanjeli batu dengan pupuk silika $300 \mathrm{~kg} / \mathrm{ha}$, sementara terendah pada hanjeli pulut pada dosis $150 \mathrm{~kg} / \mathrm{ha}$ (Nurmala et. al., 2017).

Jumlah anakan per rumpun akibat pemberian pupuk silika pada semua dosis tidak berpengaruh baik terhadap hanjeli pulut maupun batu, masingmasing hanjeli batu berkisar 4,18 - 5,13, sedangkan pada pulut berkisar 11,31 - 11,81 anakan. Terbentuknya anakan yang relatif sedikit disebabkan karena penanaman dilakukan di dalam polibag sehingga pembentukan anak tunas tidak maksimal. Hanjeli pulut bisa menghasilkan sampai 20 anakan per rumpun (Nurmala et. al., 2017).

Indeks luas daun (ILD) tidak dipengaruhi oleh pupuk silika, berkisar antara 4,3 - 5,7, demikian juga dalam pembentukan organ daun cukup tinggi dengan tingkat kesuburan tanah awal sedang. Hal ini cukup merangsang hanjeli batu dan pulut untuk membentuk daun yang baik. Indeks luas daun pada tanaman jagung berkisar antara 3,8 - 4,0 (Abdurahman, 2013).

Bobot biomassa total tidak dipengaruhi oleh pupuk silika dibandingkan tanpa silika pada masing-masing varietas. Bobot hanjeli pulut berkisar 458,42 g - 697,88 g, sementara hanjeli batu berkisar antara 209,03 - 292,53 g. Pembentukan biomassa tergambar dari data pendukung berupa tinggi, tanaman, jumlah anakan dan ILD yang memadai. Data secara lengkap disajikan dalam Tabel 1.
Pada Tabel 2 tertera jumlah srisip per rumpun tidak dipengaruhi oleh dosis pupuk silica, baik pada hanjeli pulut maupun pada hanjeli batu yang berkisar antara 38,03 - 70,43 . Srisip ini akan memunculkan malai yang berisi antara 3 - 5 biji per malai

Tabel 1. Pengaruh Biosilika terhadap Tinggi Tanaman (cm), Jumlah Anakan, ILD, dan Biomassa Total (g)

\begin{tabular}{cccccc}
\hline $\begin{array}{c}\text { Perlakuan } \\
\text { Biosilika } \\
(\mathrm{kg} / \mathrm{Ha})\end{array}$ & $\begin{array}{c}\text { Tinggi } \\
\text { Tanaman } \\
(\mathrm{cm})\end{array}$ & $\begin{array}{c}\text { Jumlah } \\
\text { Anakan } \\
\text { per } \\
\text { Rumpun }\end{array}$ & $\begin{array}{c}\text { Indeks } \\
\text { Luas } \\
\text { Daun }\end{array}$ & $\begin{array}{c}\text { Biomassa } \\
\text { Total }(\mathrm{g})\end{array}$ \\
\hline Batu & 0 & $139,9 \mathrm{bc}$ & $5,3 \mathrm{a}$ & $5,7 \mathrm{a}$ & $239,3 \mathrm{a}$ \\
$(\mathrm{J} 1)$ & 150 & $141,0 \mathrm{bc}$ & $4,2 \mathrm{a}$ & $4,5 \mathrm{a}$ & $292,5 \mathrm{a}$ \\
& 300 & $143,9 \mathrm{c}$ & $4,7 \mathrm{a}$ & $4,3 \mathrm{a}$ & $219,5 \mathrm{a}$ \\
& 450 & $136,1 \mathrm{abc}$ & $4,2 \mathrm{a}$ & $4,4 \mathrm{a}$ & $209,0 \mathrm{a}$ \\
& 600 & $130,2 \mathrm{abc}$ & $4,7 \mathrm{a}$ & $4,6 \mathrm{a}$ & $226,4 \mathrm{a}$ \\
Pulut & 750 & $132,6 \mathrm{abc}$ & $5,0 \mathrm{a}$ & $4,7 \mathrm{a}$ & $235,7 \mathrm{a}$ \\
$(\mathrm{J} 2)$ & 150 & $120,6 \mathrm{a}$ & $11,3 \mathrm{~b}$ & $5,2 \mathrm{a}$ & $697,9 \mathrm{~d}$ \\
& 300 & $126,1 \mathrm{a}$ & $12,6 \mathrm{~b}$ & $5,5 \mathrm{a}$ & $500,0 \mathrm{bc}$ \\
& 500 & $123,7 \mathrm{ab}$ & $11,5 \mathrm{~b}$ & $5,6 \mathrm{a}$ & $688,6 \mathrm{~d}$ \\
& 600 & $121,2 \mathrm{ab}$ & $11,9 \mathrm{~b}$ & $5,5 \mathrm{a}$ & $583,4 \mathrm{bcd}$ \\
& 750 & $125,5 \mathrm{ab}$ & $11,1 \mathrm{~b}$ & $5,5 \mathrm{a}$ & $637,3 \mathrm{~d}$ \\
\hline
\end{tabular}

Keterangan: Nilai rata-rata perlakuan yang diikuti oleh huruf yang dan pada kolom yang sama menunjukkan tidak berbeda nyata berdasarkan uji jarak berganda Duncan pada taraf nyata $5 \%$.

Jumlah malai per rumpun dipengaruhi oleh dosis pupuk silika (Tabel 2). Jumlah malai tertinggi (1488,4 malai) dihasilkan dari hanjeli pulut, dosis biosilika berbeda dengan tanpa pupuk yang menghasilkan malai yang rendah (750,1 kg/ha). Pada hanjeli batu tanpa biosilika menghasilkan jumlah malai yang terendah 450,9 malai dibandingkan dengan dosis $150 \mathrm{~kg} / \mathrm{ha}$ dan $750 \mathrm{~kg} / \mathrm{ha}$.

Nilai nisbah pupus akar (NPA) tidak dipengaruhi oleh adanya pupuk biosilika, kisaran nilai 2,42 - 3,12 baik pada jenis batu maupun pulut, memperlihatkan pertumbuhan vegetatif yang baik namun menghasilkan bobot akar yang tinggi pula, sehingga NPA tidak terlalu tinggi. Sebagai perbandingan, NPA pada tanaman jagung berkisar 3-5.

Pupuk biosilika berpengaruh terhadap indeks panen (IP) hanjeli pulut dibandingkan kontrol. Indeks panen hanjeli pulut yang diberi perlakuan $600 \mathrm{~kg} / \mathrm{ha}$ berbeda dengan tanpa silika. Pada tanaman jagung IP bisa mencapai $0,44-0,5$. Biosilika hanjeli pulut lebih responsif daripada batu seiring dengan peningkatan dosis sampai $600 \mathrm{~kg} / \mathrm{ha}$. 
Komponen hasil hanjeli yang berupa, bobot 100 butir, IP, kekerasan biji, dan hasil per ha disajikan dalam Tabel 3.

Tabel 2. Pengaruh Biosilika terhadap Jumlah Sisip per Rumpun, Jumlah Malai per Rumpun, NPA, dan IP

\begin{tabular}{|c|c|c|c|c|c|}
\hline \multicolumn{2}{|c|}{$\begin{array}{c}\text { Perlakuan } \\
\text { Biosilika } \\
\text { Per Ha }\end{array}$} & $\begin{array}{l}\text { Jumlah } \\
\text { Sisip } \\
\text { per } \\
\text { Rumpun }\end{array}$ & \multirow{2}{*}{$\begin{array}{c}\text { Jumlah } \\
\text { Malai } \\
\text { per } \\
\text { Rumpun } \\
450,9 \mathrm{a}\end{array}$} & \multirow{2}{*}{$\begin{array}{c}\text { Nisbah } \\
\text { Pupus } \\
\text { Akar } \\
2,96 \text { a }\end{array}$} & \multirow{2}{*}{$\begin{array}{l}\text { Indeks } \\
\text { Panen } \\
0,12 \text { a }\end{array}$} \\
\hline Batu & 0 & $52,2 \mathrm{ab}$ & & & \\
\hline \multirow[t]{5}{*}{ (J1) } & 150 & $48,8 \mathrm{ab}$ & $769,2 \mathrm{~b}$ & $3,01 \mathrm{a}$ & $0,15 \mathrm{a}$ \\
\hline & 300 & $59,5 \mathrm{bc}$ & $498,3 \mathrm{ab}$ & $3,12 \mathrm{a}$ & $0,19 \mathrm{ab}$ \\
\hline & 450 & $38,0 \mathrm{a}$ & $641,9 \mathrm{ab}$ & $2,69 \mathrm{a}$ & $0,18 \mathrm{ab}$ \\
\hline & 600 & $56,6 \mathrm{ab}$ & $758,1 \mathrm{ab}$ & $2,53 \mathrm{a}$ & $0,21 \mathrm{abc}$ \\
\hline & 750 & $51,4 \mathrm{ab}$ & $850,2 \mathrm{~b}$ & $2,78 \mathrm{a}$ & $0,22 \mathrm{abc}$ \\
\hline Pulut & 0 & $70,4 \mathrm{c}$ & $750,1 \mathrm{ab}$ & $2,79 \mathrm{a}$ & 0,32 cde \\
\hline \multirow[t]{5}{*}{ (J2) } & 150 & $64,7 \mathrm{bc}$ & $1458,3 \mathrm{c}$ & $2,83 \mathrm{a}$ & 0,40 ef \\
\hline & 300 & $67,2 \mathrm{bc}$ & 1473,8 c & $2,54 \mathrm{a}$ & $0,27 \mathrm{bc}$ \\
\hline & 500 & $71,4 \mathrm{c}$ & 1488,4 c & $2,74 \mathrm{a}$ & 0,36 def \\
\hline & 600 & $64,1 \mathrm{bc}$ & $1471,4 \mathrm{c}$ & $2,42 \mathrm{a}$ & $0,44 \mathrm{f}$ \\
\hline & 750 & $65,8 \mathrm{bc}$ & $1373,2 \mathrm{c}$ & $2,59 \mathrm{a}$ & 0,33 def \\
\hline
\end{tabular}

Keterangan: Nilai rata-rata perlakuan yang diikuti oleh huruf yang dan pada kolom yang samamenunjukkan tidak berbeda nyata berdasarkan uji jarak berganda Duncan pada taraf nyata $5 \%$.

Tabel 3. Pengaruh Biosilika terhadap Bobot 100 biji (g), Kekerasan Biji, dan Hasil/Ha

\begin{tabular}{llccc}
\hline \multicolumn{2}{c}{$\begin{array}{c}\text { Perlakuan } \\
\text { Biosilika } \\
\text { Per Ha }\end{array}$} & $\begin{array}{c}\text { Bobot 100 } \\
\text { Biji } \\
(\mathrm{g})\end{array}$ & $\begin{array}{c}\text { Kekerasan } \\
\text { Biji } \\
(\mathrm{lbf})\end{array}$ & $\begin{array}{c}\text { Hasil/Ha } \\
(\mathrm{Kg})\end{array}$ \\
\hline Batu & 0 & $12,2 \mathrm{a}$ & $17,26 \mathrm{~b}$ & 704,5 \\
$(\mathrm{~J} 1)$ & 150 & $13,4 \mathrm{a}$ & $26,33 \mathrm{~cd}$ & 911,5 \\
& 300 & $13,9 \mathrm{a}$ & $28,16 \mathrm{~cd}$ & 1018,4 \\
& 450 & $14,4 \mathrm{a}$ & $27,33 \mathrm{~cd}$ & 972,2 \\
& 600 & $13,6 \mathrm{a}$ & $24,90 \mathrm{c}$ & 891,2 \\
Pulut & 750 & $14,0 \mathrm{a}$ & $31,00 \mathrm{~d}$ & 1103,7 \\
$(\mathrm{~J} 2)$ & 0 & $14,7 \mathrm{a}$ & $7,57 \mathrm{a}$ & 1186,7 \\
& 150 & $15,8 \mathrm{a}$ & $8,51 \mathrm{a}$ & 4232,0 \\
& 300 & $16,9 \mathrm{a}$ & $8,30 \mathrm{a}$ & 4209,0 \\
& 500 & $15,2 \mathrm{a}$ & $8,47 \mathrm{a}$ & 4904,7 \\
& 600 & $15,8 \mathrm{a}$ & $8,38 \mathrm{a}$ & 4473,5 \\
& 750 & $15,0 \mathrm{a}$ & $9,38 \mathrm{a}$ & 4741,9 \\
\hline
\end{tabular}

Keterangan: Nilai rata-rata perlakuan yang diikuti oleh huruf yang dan pada kolom yang samamenunjukkan tidak berbeda nyata berdasarkan uji jarak berganda Duncan pada taraf nyata $5 \%$.

Bobot 100 biji tidak dipengaruhi oleh pupuk biosilika, namun menunjukkan bobot biji jenis batu relatif lebih rendah daripada pulut dengan nilai berkisar 12,32 g - 16,88 g, ternyata mencapai nilai lebih tinggi daripada deskripsi sementara menurut Nurmala dan Irwan (2007) berkisar $6,5 \mathrm{~g}-7,5 \mathrm{~g}$.
Hasil diperoleh dari data per rumpun yang dikonversi dengan populasi per ha 23.000 tanaman hanjeli, dengan asumsi jarak tanam 70 x60 cm. Hanjeli batu cenderung hasilnya lebih rendah berkisar antara 704,5 - 1113,7 kg/ha; dari pada hanjeli pulut berkisar 1186,7 - 4904,7 $\mathrm{kg} / \mathrm{ha}$. Sebagaimana ditunjukkan oleh data pendukung komponen pertumbuhan dan hasil.

Semua dosis biosilika berpengaruh terhadap kekerasan biji hanjeli dibandingkan kontrol, yaitu pada hanjeli batu yang berbeda nyata dengan nilai berkisar 17,6 - 31,0 lbf. Nilai kekerasan jenis pulut berkisar antara 7,57 - 9,38 lbf, tidak berbeda pada semua dosis biosilika. Jenis batu sangat responsif terhadap kekerasan biji seiring dengan peningkatan dosis biosilika.

\section{Kesimpulan}

Pupuk biosilika berpengaruh terhadap jumlah malai per rumpun, indeks panen, dan kekerasan biji hanjeli pada kandungan silika tanah tinggi. Dosis $150 \mathrm{~kg} / \mathrm{ha}$ dan $750 \mathrm{~kg} / \mathrm{ha}$ pada hanjeli batu berpengaruh terhadap jumlah malai per rumpun dibandingkan kontrol. Dosis $600 \mathrm{~kg} / \mathrm{ha}$ memberikan IP terbaik dibandingkan kontrol pada hanjeli pulut. Semua dosis silika berpengaruh terhadap kekerasan biji hanjeli batu dibandingkan kontrol.

\section{Daftar Pustaka}

Abdurahman, T. 2013. Dinamika Pertumbuhan dan Hasil Jagung akibat Pemberian Amelioran Lumpur Laut Cair dan Pupuk Kotoran Sapi pada Tanah Gambut. Disertasi Doktor Program Pasca Sarjana Fakultas Pertanian Universitas Padjadjaran.

Djajadi, K.S. 2013. Silika (Si) Unsur Hara Penting dan Menguntungkan Bagi Tanaman Tebu (Saccharum officinarum) Balai Penelitian Tebu vol 12 (1).

Malivchenkov, V.V, and D.V. Calvert. 2002. Silicon as Benevicial Element For Sugarcane. Journal American Society of Sugarcane Tecnologist (22):21-30.

Meyer, J.H., and M.C. Keeping. 2000. Review of Research into The Role of Silicon for Sugercane Production Proc. S. Afr Sug. Technol. Ass. (74):29-40. 
Nurmala, T., Ruminta, dan F.Y. Wicaksono. 2017. Pengembangan Pangan Lokal Hanjeli Sebagai Pangan Multifungsi dalam Rangka Pemberdayaan Petani di Lahan Marjinal. Prosiding Fakultas Pertanian UNPAD.

Nurmala, T., dan A.W. Irwan. 2007. Pangan Alternatif Berbasis Serealia Minor. Giratuna Bandung.

Rachman, H.P.S. dan M. Ariani. 2008. Penganekaragaman Konsumsi Pangan di Indonesia, Permasalahan dan Implikasi
Untuk Kebijakan dan Program Analisis Kebijakan Pertanian vol 6(2): 140-154.

Ruminta, T. Nurmala, and F.Y. Wicaksono. 2017. Growth and Yield of Jobs tears (Coix lacryma Jobi) response to difference type of Oldeman Climate Classification and row spacing in West Java Indonesia. Journal of Agronomy vol 16:76-82.

Syafrudin. 2011. Pengaruh Silika terhadap Hasil dan Efisiensi Pemupukan P pada Tanaman Jagung. Seminar Nasional Serealia. 